\title{
Linking Watershed Scales through Altered Waterways
}

\author{
Mason Johnson, Katherine Clancy \\ College of Natural Resources, University of Wisconsin at Stevens Point, Stevens Point, USA \\ Email: kclancy@uwsp.edu
}

How to cite this paper: Johnson, M. and Clancy, K. (2016) Linking Watershed Scales through Altered Waterways. Journal of Water Resource and Protection, 8, 885-904. http://dx.doi.org/10.4236/jwarp.2016.810073

Received: July 19, 2016

Accepted: August 28, 2016

Published: August 31, 2016

Copyright $\odot 2016$ by authors and Scientific Research Publishing Inc.

This work is licensed under the Creative

Commons Attribution International

License (CC BY 4.0).

http://creativecommons.org/licenses/by/4.0/

\begin{abstract}
Nested hierarchy theory advances the idea that rivers have a fractal dimension where processes at the catchment scale $(>1 \mathrm{~km})$ control processes at the reach or mesoscale $(100 \mathrm{~m})$ and microscale $(1-10 \mathrm{~m})$. Largely absent from this work is a mesoscale link to the larger and smaller scales. We used stream alteration classifications to provide this link. We used orthophotographs, land cover, and LiDAR derived terrain models to classify stream alterations within four watersheds. We compared phosphorus point data with watershed, sub-watershed, and 100-meter buffers around the point data. In the predominately urban watershed, the $100 \mathrm{~m}$ buffer scale correlated better with phosphorus levels. In the predominately agricultural watershed, the sub-watershed scale correlated with phosphorus levels better. We found adding the classification of the stream alteration type clarified anomalously low phosphorus levels.
\end{abstract}

\section{Keywords}

Nested Hierarchy Theory, Altered Waterways, Landuse, Water Quality

\section{Introduction}

Nested hierarchy theory (NHT) advances the idea that rivers have a fractal dimension where processes at the larger watershed scale $\left(>10^{2} \mathrm{~km}\right)$ and sub-watershed $(>1 \mathrm{~km})$ control processes at the reach or mesoscale $(100 \mathrm{~m})$ and microscale $(10-1 \mathrm{~m})$ [1]. This theory is clearly demonstrated for some of the phenomenon that control the hydraulics of a stream, such as the geology of the watershed that impacts watershed relief, reach slope, and mesoscale substrate [1].

The Frissell et al., 1986 NHT provided a conceptual framework for abiotic and biotic projects designs, data collection and analysis. The original RCC developed from geomorphic models of rivers having "dynamic equilibrium" [2]; the ability of the width, 
depth, and slope to affect changes in runoff and sediment. The RCC study focused on the linkage between organic matter inputs and watershed landuse. The RCC theory differs slightly from NHT in that RCC views the river as a smooth continuous ecosystem without discontinuities and sees heterogeneity within the system as "noise" [3]; whereas, NHT associates these discontinuities with the influence of different scales within the watershed.

NHT assumes large scale processes within a river influence smaller scale processes. Of interest is landuse's role at the watershed and reach scale, particularly agriculture, urban, forest, and wetland. In general water quality samples usually have lower sediment and/or pollutants in regions with lower percentages of agriculture and urban. Prior studies have determined that human alteration to the landscape yields a response across many scales [4]-[8]. For example, agricultural landuse is associated with higher volumes of sediment and nutrients than most other landuse types. High levels of sediment and nutrient levels measured at a predominantly agricultural watershed's outlet are expected. At the reach scale, the increased sediment load may increase scour and alterations to the channel's slope, depth, and width. Sedimentation at the microhabitat scale can change substrate and drastically alter the benthic zone and habitat availability for benthic invertebrates. The resulting loss of habitat and food source affects larger invertebrates at multiple scales. These changes at the smaller scale provide responses that influences peak flow, sediment storage, and erosion at downstream reaches at the watershed scale.

The net result of 30 years of projects investigating watershed scales and their relationship to landuse has not resulted in a consensus [9]. Two central issues concerning NHT and landuse remain unclear. The first issue is which land use scale (watershed or reach) provides the best predictor of water quality or ecological health. For example, how relevant is the landuse of the watershed at the reach scale. The second issue is how to use information determined at one scale to link it to others. For example, how can information be upscaled from point or reach scales to the watershed scale or downscaled from the watershed scale to point or reach scales.

Studies investigating the optimal scale of landuse to predict water quality have yielded opposing results. Research in a wide variety of landuses has found that watershed scale landuse factors may not be strongly correlated with water quality indicators at the reach or microhabitat scale. Researchers have found that riparian vegetation, bank condition, and landuse directly adjacent to the site are better indicators of water quality [3] [10]. In a comprehensive study of 79 watersheds within Minnesota, Wisconsin, and Michigan, Wang et al. (2003) found that the range of biotic and abiotic indicators collected at the watershed and riparian scales had only a baseline impact on the prediction of fish assemblages while data collected at the point scale yielded a prediction [7].

Other studies suggest that watershed scale factors play an important role in understanding the smaller scales [11]. In a study including 72 sampling sites in Belize, Esselman and Allan (2010) found data at the watershed scale explained the variation in fish 
assemblages better than data collected at the reach scale (mesoscale) [12].

Some papers suggest that the confounding factor reducing the efficacy of a landuse evaluation of water quality and habitat is the location of environmental factors [6]-[9]. Controls, such as impoundments, culverts, and bridges, impact upstream reaches differently than downstream reaches. Both segments suffer from a lack of flow variability, but upstream segments are more prone to flooding and sedimentation, while downstream regions are sediment-starved with low flows.

In a comprehensive review of the landscapes and their interactions with streams, Allen, 2004 identifies and summarizes six principle environmental factors that affect rivers: 1) sedimentation; 2) nutrient enrichment; 3) contaminant pollution; 4) hydrologic alteration; 5) riparian clearing and opening; and 6) loss of large woody debris [13]. These environmental factors are often correlated with types of landuse, particularly urban and agricultural landuse, which have a high degree of human impact. Of the six, hydrologic alteration can be identified and classified using Geographical Information Systems (GIS) techniques. Hydrologic alterations are also highly correlated with reaches that exhibit the other environmental factors. Indications where stream channels have been altered or modified due to anthropogenic changes can assist in providing the mesoscale or reach scale link to the larger and smaller scales and may explain the inconsistencies in studies that focus on the watershed and micro scales.

Management of watersheds, especially those impacted by anthropogenic landuse (e.g. agricultural and urban) is driven by a need to maintain water quality at set levels and to manage sampling costs. Predictive water quality models using landuse characteristics at the watershed scale often fail to target specific regions within the watershed requiring remediation [9].

In this paper, we identify and classify hydraulic alterations using spatial data. Our hypothesis is twofold. First, we expect a higher percentage of altered waterways will be found in watersheds with higher amounts of anthropogenic landuse; and second, that water sampling points will correlate best with landuse buffers from the immediate location. We also expect that anomalously low or high readings will be better accounted for by their hydraulic classification. We define our research scales as follows: large scale (watersheds: approximately $130 \mathrm{~km}^{2}$ ), intermediate scales or mesoscales (sub-watershed $(10-0.05) \mathrm{km}^{2}$ and stream segments $10 \mathrm{~km}$ ), and microscale (100-meter buffers around water quality sampling points, $0.1 \mathrm{~km}^{2}$ ).

\section{Site Description}

The selected hydrologic unit code 12 (HUC12) watersheds reside in four regionally different locations and have varying landuse in Wisconsin: Swamp Creek-north central, West Fork Knapp Creek-south central, Bass-Stevens Creek-south central, and Milwaukee River-south east (Figure 1). Swamp Creek is located in the Upper North Fork Flambeau River drainage in Iron and Ashland counties. It has a drainage area of 114.5 square $\mathrm{km}$ with a total of 72.9 stream $\mathrm{km}$ that drains into the Flambeau River. Swamp Creek is predominantly forest and woody wetland in Iron and Ashland counties. West 


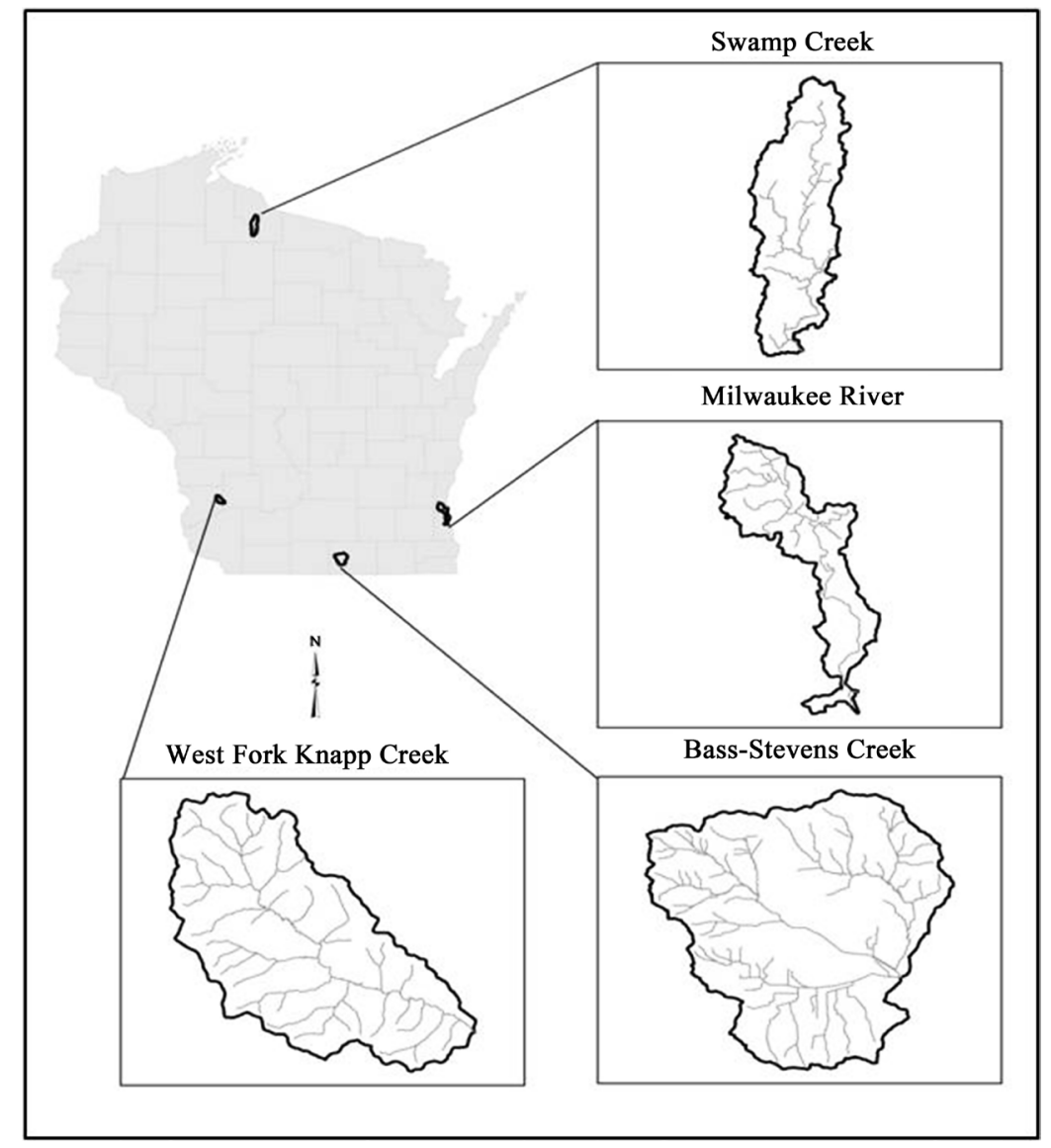

Figure 1. Locations of HUC12 watersheds and stream vector hydrology from Wisconsin.

Fork Knapp Creek is located in Crawford and Richland counties in the Driftless Area. It has a drainage area of 47.9 square $\mathrm{km}$ with a total of 75 stream $\mathrm{km}$. West Fork Knapp Creek, a cold headwater stream of the Wisconsin River, is dominated by forest landuse. Bass-Stevens Creek watershed is located in Rock County and has intensive agricultural activity; 70 percent of the total area. Bass-Stevens Creek is classified as a warm headwater stream to Rock River watershed and was placed under Total Maximum Daily Load (TMDL) study in 2011 [14]. It has a drainage area of 120.7 square $\mathrm{km}$ with a total of 150.5 stream km. The Wisconsin Department of Natural Resources (WDNR) has classified Bass-Stevens Creek watershed as impaired [15]. The Milwaukee River watershed is located in Milwaukee and Ozaukee counties and drains directly into Lake Michigan. Milwaukee River is dominated by urban landuse that makes up approximately 80 percent of its total land. It has a drainage area of 108.3 square $\mathrm{km}$ with a total of 75.2 stream $\mathrm{km}$.

\section{Methods}

\subsection{Altered Stream Data Acquisition}

Data used for classification of altered hydrology came from state and federal sources. 
An existing geospatial stream vector file from the WDNR [16] was imported into ArcMap 10.2. The WDNR originally digitized stream features from many 1:24,000 scale United States Geological Survey (USGS) topographic quadrangle maps. Stream vector files were clipped to the extent of four regionally different Watershed Boundary Dataset (WBD) HUC12 watersheds, West Fork Knapp Creek, Bass Creek, Swamp Creek, and Milwaukee River [17]. Lake data was also obtained from the WDNR (WDNR, 2007). One-meter Light Detection and Ranging (LiDAR) data was downloaded from the Wisconsin View website and extracted (Wisconsin View, 2011). Hill shade was derived from one-meter LiDAR data. Ten-meter digital elevation data was used for one of the watersheds devoid of LiDAR data. The United States Department of Agriculture's National Agricultural Imaging Program (NAIP) 2013 aerial imagery was also obtained from the Wisconsin View website for Crawford and Rock Counties [18]. Imagery from 1938 was downloaded from the Wisconsin Historical Aerial Image Finder [19]. The 1938 aerial imagery was geo-referenced and rectified using Arc Map. National Wetlands Inventory (NWI) data was downloaded from the United States Fish and Wildlife Service NWI Mapper website [20]. USGS National Land Cover Database (NLCD) 2011 data was downloaded from the Multi-Resolution Land Characteristics Consortium [21]. United States Department of Agriculture (USDA) Cropland Data Layer (CDL) 2014 data was acquired from the National Agricultural Statistics Service [22]. NLCD 2011 and CDL 2014 rasters were extracted for each HUC12 watershed. Road data was accessed from Wisconsin Department of Transportation 2003 dataset [23].

\subsection{Altered Stream Data Pre-Classification}

Prior to determining altered hydrology, fields were populated in the stream vector feature class table. Altered water course type (AWC-type) with domains: (1) Altered, (2) Natural, (3) Impounded, and (4) No Definable Channel. Sinuosity was also added and calculated using the ArcPy Sinuosity tool (ArcGIS ver 10.2). This takes the distance along all vertices on the stream channel from start point to endpoint and divides by the straight-line distance between the two points. A sinuosity value approaching zero represents more sinuous while a value approaching one is less sinuous or straighter. Each stream segment was assessed separately. If a stream segment lies in two different classifications, the segment would be split and classified appropriately. For example, a long stream segment that crossed into an agriculturally dominated area and became less sinuous would be classified as altered. If the other portion of the same segment were more sinuous and resided in a forest-dominated area with no apparent anthropogenic changes, this portion would be classified as natural. Classification of altered hydrology followed the Minnesota Geospatial Information Office (MnGeo) for altered watercourse framework [24]. MnGeo prepared a statewide-altered hydrology geospatial layer for the Minnesota Pollution Control Agency (MPCA) using the USGS National Hydrography Dataset (NHD) flow lines. The MPCA used this dataset for water quality monitoring and assessment programs used to provide information about stream habitat. Although classification closely followed the altered watercourse determinations by 
MnGeo, some modifications were necessary for this study. MnGeo's classification only included streams that exceeded 150 meters in length, while this study analyzes streams of any length. Instead of using the USGS NHD flow line vector and its corresponding Hydro Event Manager Toolbar for editing, the Wisconsin hydrology dataset was used with basic ArcMap editing.

\subsection{Altered Stream Data Classification: Altered}

In order to classify a stream reach as altered, adjacency to agricultural operations, sinuosity, and general anthropogenic alterations were assessed. Each stream flagged as potentially altered was compared to certain acquired spatial layers. Recent 2013 aerial imagery was compared with the original $24 \mathrm{~K}$ stream's digital raster graphic (DRG). If drainage pattern was similar, LiDAR hill shade and digital elevation model data were compared with the streams. Lastly, 2013 and 1938 aerial imagery along with LiDAR data were compared. Stream channelization not displayed in the DRG but apparent in recently acquired LiDAR was considered altered.

Historic and recent aerial imagery comparisons also aided in displaying even the smallest alterations. Streams that were previously natural may have been altered through ditching. A strong predictor of ditching is a stream's adjacency to agricultural landuse and changes in sinuosity. The presence of any linear feature or structure that represents human interaction with nearby hydrology results in a stream classification of altered. Bank stabilization, levee construction, or cement structures constraining flow will alter a stream's natural course and are examples of types stream segments that would be considered altered.

Agricultural landuse is associated with ditching, draining, and channel straightening, so stream segments within a prominently agricultural area with low sinuosity were examined closely (Figure 2). Recent 2013 aerial imagery indicates alteration in the streams' flow from earlier 1938 imagery (Figure 3). In some cases, stream features from

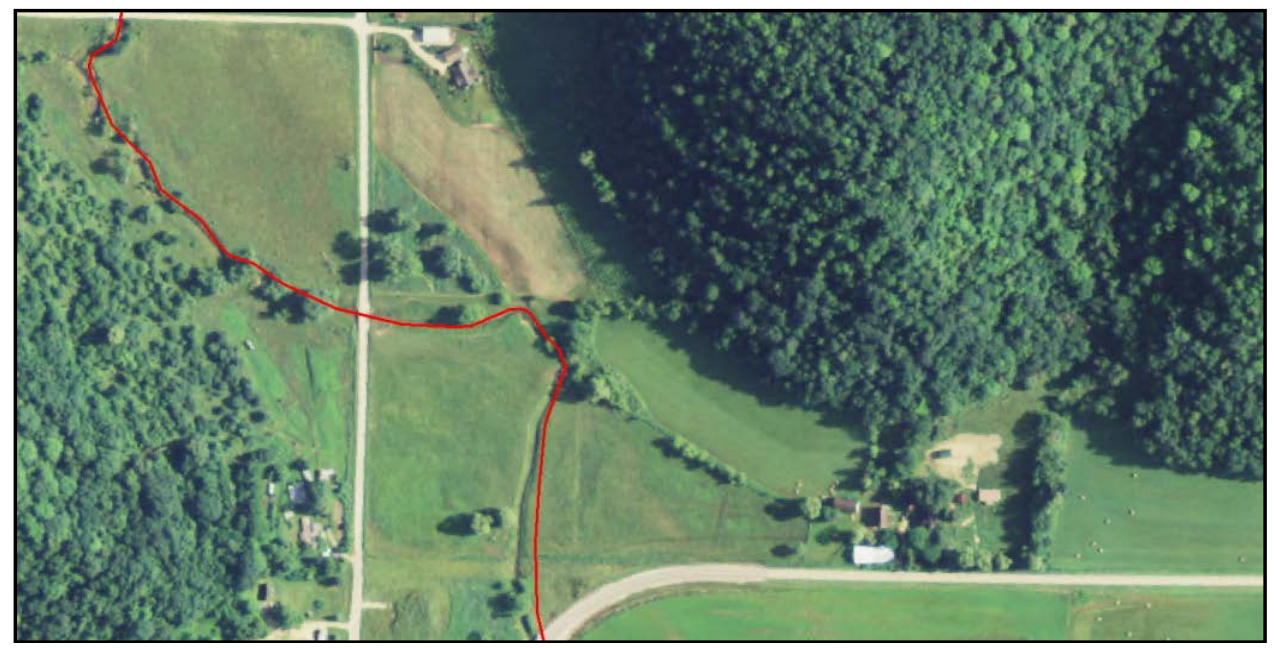

Figure 2. Altered stream reach in west fork Knapp creek watershed. Note surrounding agricultural land and roads disrupting natural flow and decreasing sinuosity. 


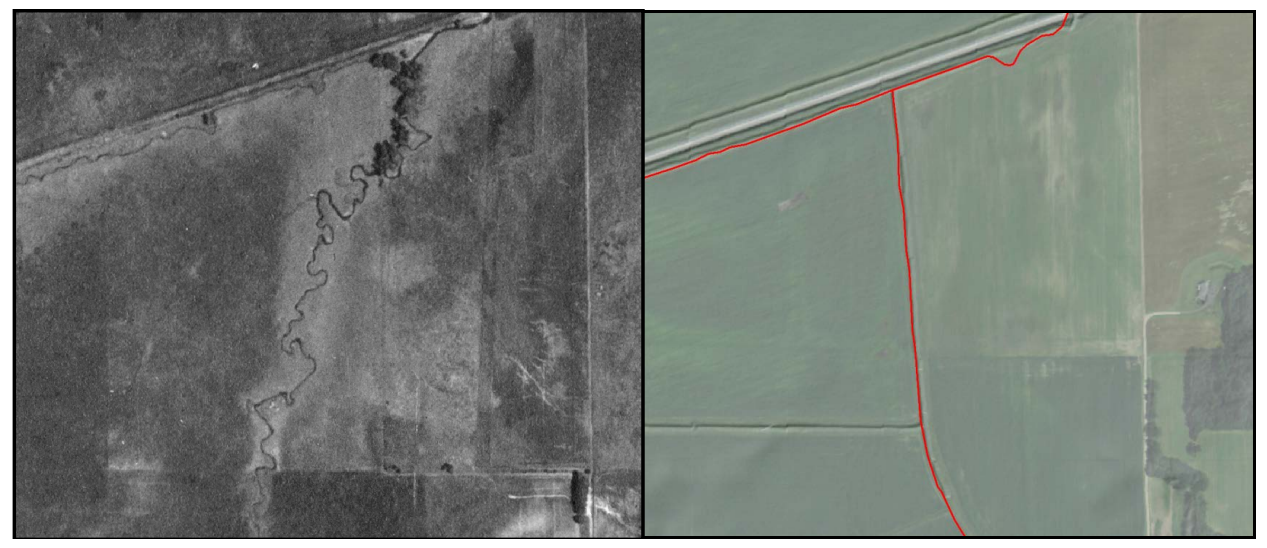

Figure 3. Aerial imagery from 1938 (left) and 2013 NAIP imagery (right) in bass creek watershed. Notice the change in direction the watercourse takes after ditching indicating alterations.

prior aerial imagery are unaltered even though increased agriculture is present. We determined if channel sinuosity is retained and there are no structures or evident changes, the stream segment is classified as natural. Stream segments that closely border a road or other obstructions such as water and sediment control basins are classified as altered. Stream segments with forested regions around them but are adjacent to roads are also considered altered because roads change the channel's natural flow path (Figure 4).

\subsection{Altered Stream Data Classification: Natural}

Sinuosity in headwater streams was less important in steeper gradients. Headwater streams in high relief regions do not have the hydraulic capability of creating meandering channels. Stream segments adjacent to an expanse of forest and distant from agricultural impacts and any manmade structures were indefinitely classified as natural (Figure 5). However, a stream reach surrounded by agriculture can still be considered natural. If the stream resided in an actively farmed region, sinuosity would be analyzed from previous aerial imagery (Figure 6). Higher order streams, such as Milwaukee River, exhibit a decreased sinuous channel. A decrease in sinuosity can be attributed to higher discharge resulting in a less defined channel [25]. Even though heavy urban landuse surrounds the stream, structures are built far enough away to not alter flow.

Wetlands information was accessed by NWI wetlands inventory and was draped over the stream layer. Noticeable wetlands that surround a stream and are considered functional were classified as natural. However, indications of a "dried-up" wetland are considered altered [24]. Wetlands placed on a ditched watercourse to remove excess nutrients or improve habitat that essentially dry-up wetland are not considered a natural phenomenon.

\subsection{Altered Stream Data Classification: Impounded}

Water body features that interrupt river systems are often anthropogenic. Using the Wisconsin lakes data and prior aerial imagery, impounded watercourses were identified. Water body features that were not observed in 1938 aerial imagery but were found 


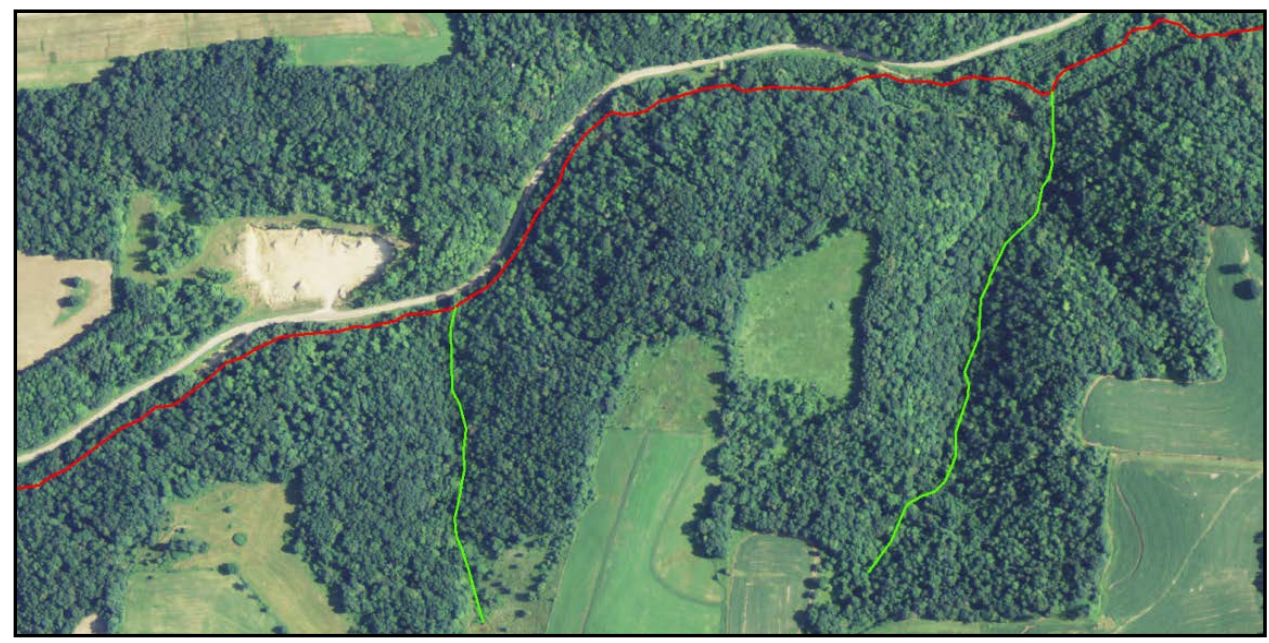

Figure 4. This reach (red) borders a road in Knapp creek watershed. Streams that follow roads in this particular system indicate altered hydrology even though surrounding landuse is forested.

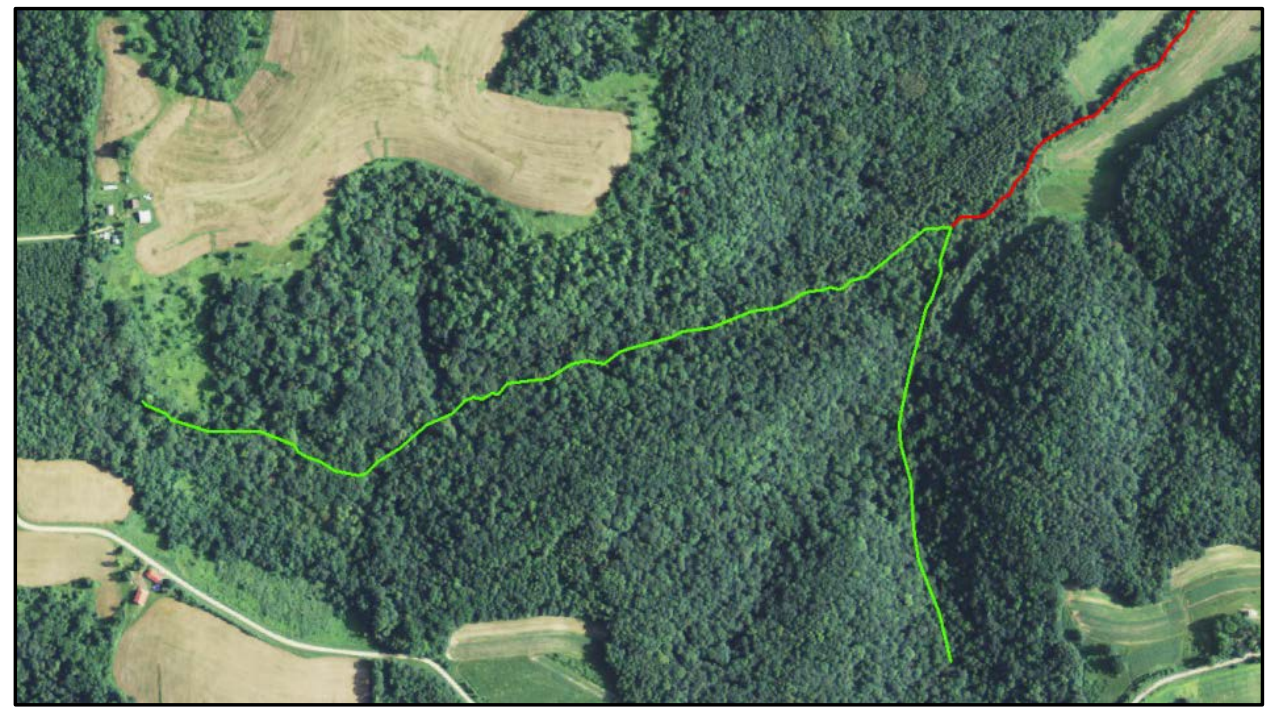

Figure 5. Natural headwater streams (green) within forested region in Knapp creek watershed. Notice the altered stream (red) surrounded by agriculture.

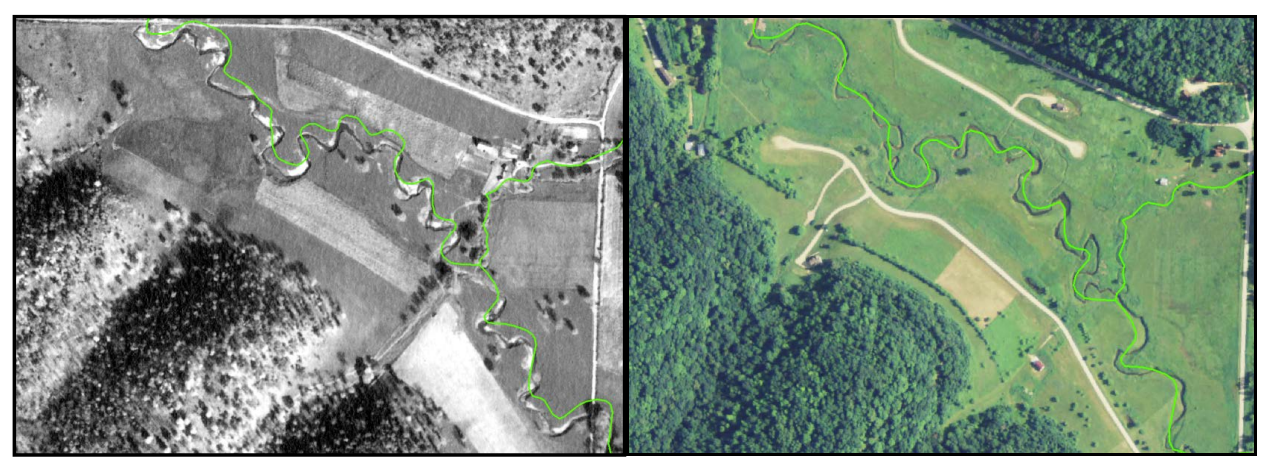

Figure 6. Natural stream within heavy agriculture in 1938 (left) and 2013 (right) in Knapp creek watershed. Note sinuosity is not disturbed and natural flow is retained. 
in 2013 aerial imagery indicate an anthropogenic structure (Figure 7). It is important to look carefully at each stream on aerial imagery without a vector file. The stream vectors previously digitized from maps may not represent true flow. On the DRG from the USGS the stream in Figure 7 appears to be impounded. After close observation and analysis of hill shade and aerial imagery, the stream actually deviates from a water body (Figure 8). The stream would be classified as natural because flow is not impeded due to the ponded structure. Linear features constructed on waterways are unnatural and indicate impoundment. Obstructions, such as beaver dams that may result in ponding are not considered impoundments. Beaver dams eventually take the natural course of breaking down and washing downstream. Wetlands that generate standing water are also not considered impoundments.

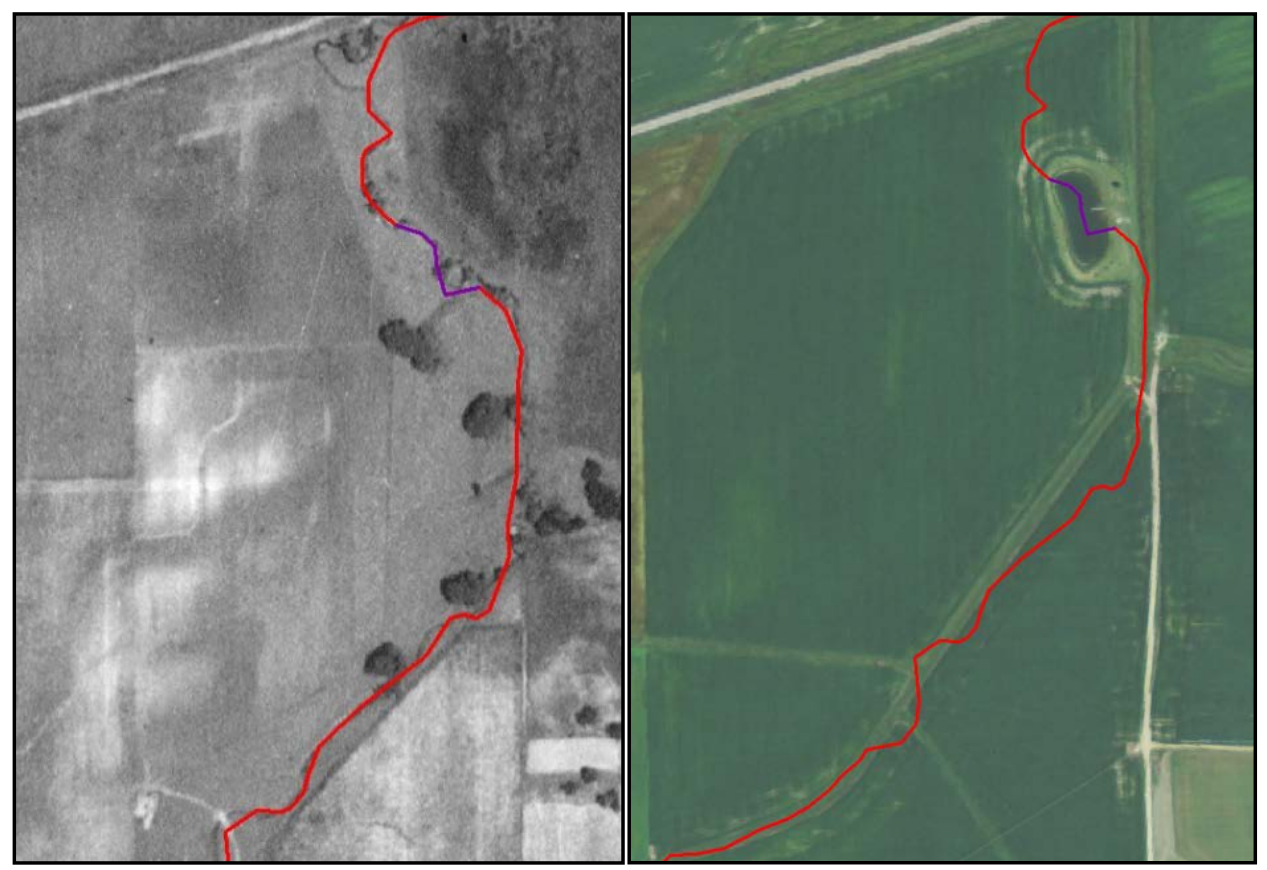

Figure 7. Impounded (purple) watercourse in bass creek watershed. Water body not present in 1938 (left), but present in 2013 (right).

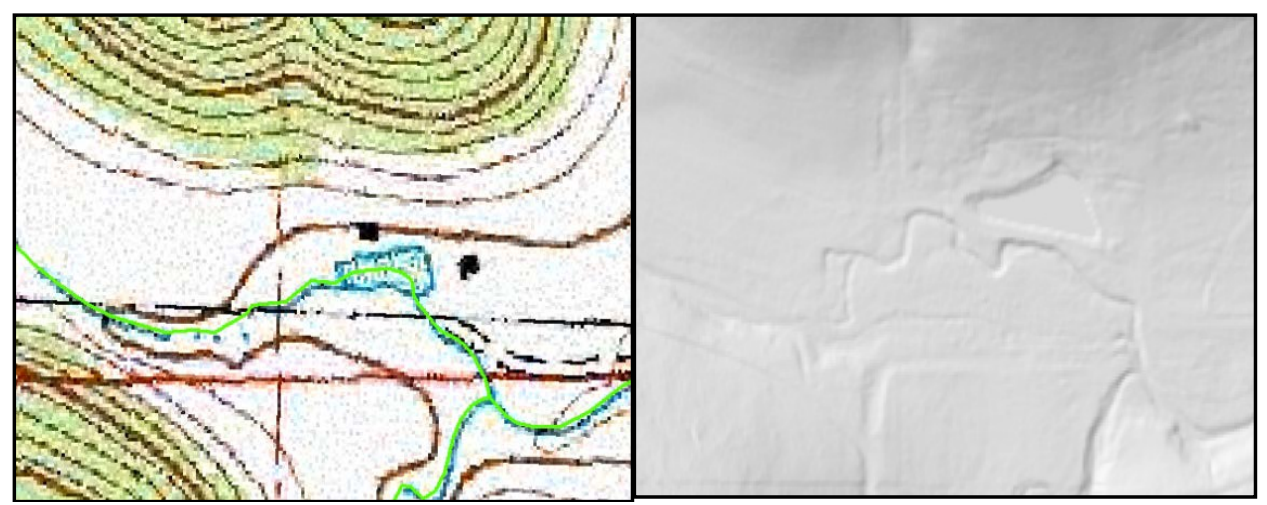

Figure 8. Watercourse seems to be impounded by a pound in the DRG (left), but hillshade (right) actually displays stream bypassing pound. Classification: Natural. 


\subsection{Altered Stream Data Classification: No Definable Channel}

Streams delineated from historic maps and aerial imagery can change course or disappear altogether over time. It is often hard to define any path that these streams take which in turn makes them harder to classify. Stream vectors that cross tillage land with no distinct flow path are considered to have no definable channel. Even if a stream looks distinct and well definable from an aerial imageries view, analyzing LiDAR data can assist in determining if a watercourse exists. The non-existent stream that is not definable through LiDAR draped over hill shade is classified as no definable channel. Another indicator of a lack of definable channel is a stream's path in relation to tillage. If a stream's path is perpendicular to tillage lines, the effective drainage direction of that reach is destroyed. A path is no longer definable from either aerial imagery or LiDAR.

\subsection{Water Quality Data}

Water quality sampling data were obtained from the WDNR sampling and volunteer monitoring program and Environmental Protection Agency (EPA) Storage and Retrieval and Water Quality Exchange (STORET) and combined into a statewide database [26]. Data points were collected from 1961 to 2015, with the majority of data collected in the last three years. Within the data set is a wide array of water quality indicators. We chose total phosphorus ( $\mathrm{mg} / \mathrm{l})$ as a water quality indicator because it is often paired with landuse and the abundance of the data for this indicator [4]. The watersheds with low anthropogenic impact, West Fork Knapp, Swamp Creek have very few sampling points $(\mathrm{n}=1)$ and no available total phosphorus data. The urban watershed, the Milwaukee River (Figure 9), and the agricultural watershed, Bass-Stevens Creek (Figure 10), have 25 and 8 phosphorus sampling points, respectively. For the Milwaukee River watershed, the sampling points had phosphorus data with an average of 50 measurements per point. Bass-Stevens had an average 7 measurements per point.

\subsection{Watershed Scale}

We divided Milwaukee and Bass-Stevens watersheds into sub-watersheds using the sampling points as outlets. The watersheds were delineated using Arc Map 10.2's hydrology toolbox. For Milwaukee River, the sub-watersheds ranged from 8 to $104 \mathrm{~km}^{2}$. For Bass-Stevens Creek watershed, the sub-watersheds ranged from 0.02 to $5.6 \mathrm{~km}^{2}$. We designate these as "watershed scale". We also used the Arc Map 10.2's buffer tool to create a $100 \mathrm{~m}$ buffer around each point. We designate these as "reach" scale. For each sub-watershed and $100 \mathrm{~m}$ buffer, we extracted landuse [21] percentages and compared them to Storage and Retrieval and Water Quality Exchange's (STORET) average total phosphorus $(\mathrm{mg} / \mathrm{L})$.

\subsection{Statistics}

We compared total phosphorus from the point data to major landuse within the subwatersheds and the $100 \mathrm{~m}$ buffers. The Mann Kendall trend test, a nonparametric statistical hypothesis, was used to evaluate the significance of upward or downward 


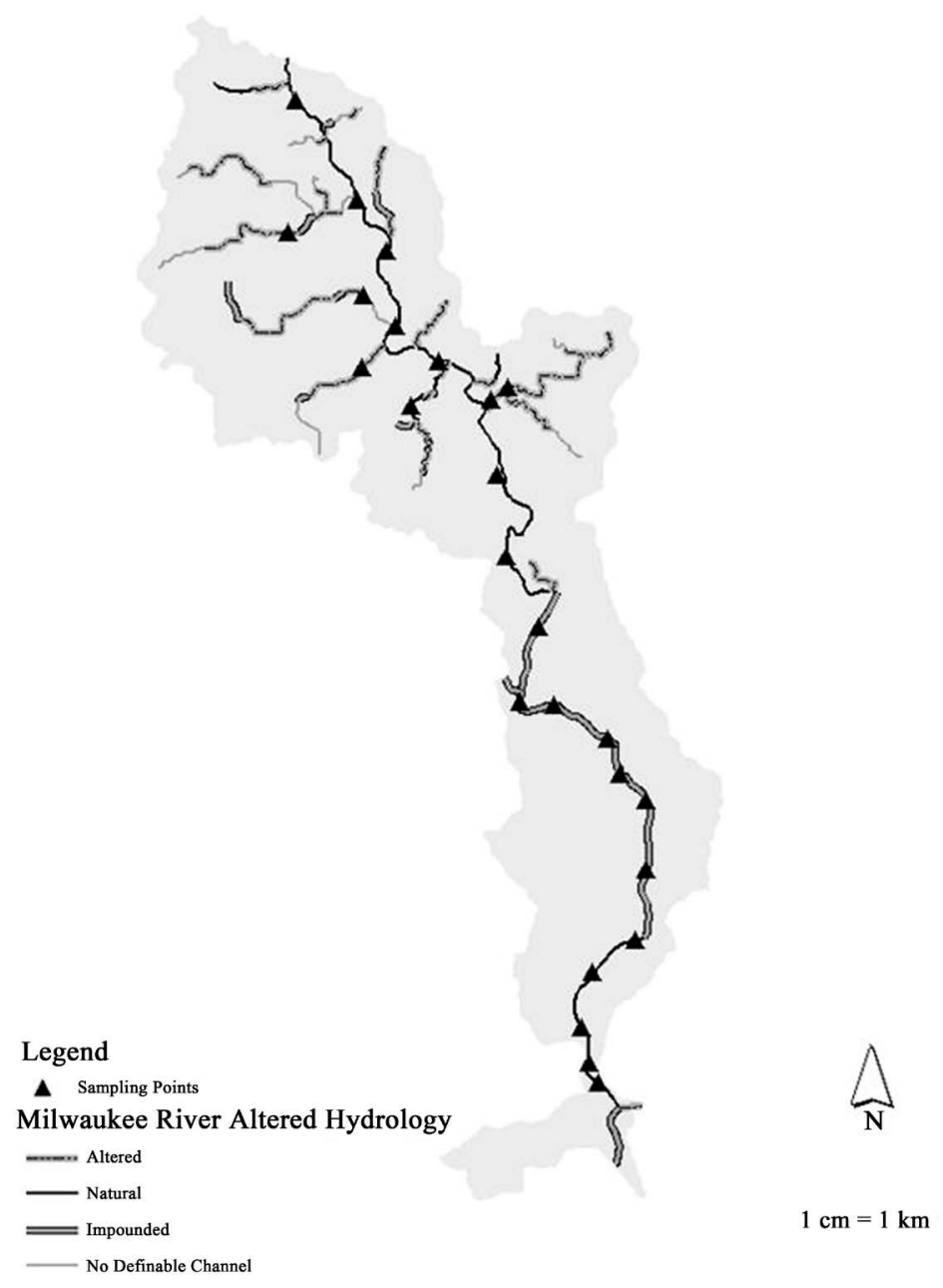

Figure 9. Milwaukee river altered waterways. Note the diversity of altered waterways within the watershed. Sampling points within the box fall along the natural portion of the Milwaukee river. These sampling points have very low total phosphorus but nearly 100 percent urban landuse within the sub-watershed and $100 \mathrm{~m}$ buffers.

monotonic trends using Minitab 17. Descriptions of the Mann Kendall trend test are well cited in published research literature [27] as well as described in statistical manuals such as [28] [29]. We examined the strength of the regression and correlation and its p-value using Microsoft's Excel 2010 for total phosphorus point data versus landuse percentage (for both sub-watershed and $100 \mathrm{~m}$ buffer).

\section{Results}

\subsection{Altered Waterways}

USGS 2011 and USDA Cropland 2014 data percentages were extracted for each watershed (Table 1). The percentage of altered waterways were determined for each watershed and summarized in Figure 11. For the agriculturally dominated watershed, Bass-Stevens Creek, the results showed a greater percentage of altered streams (95 per- 


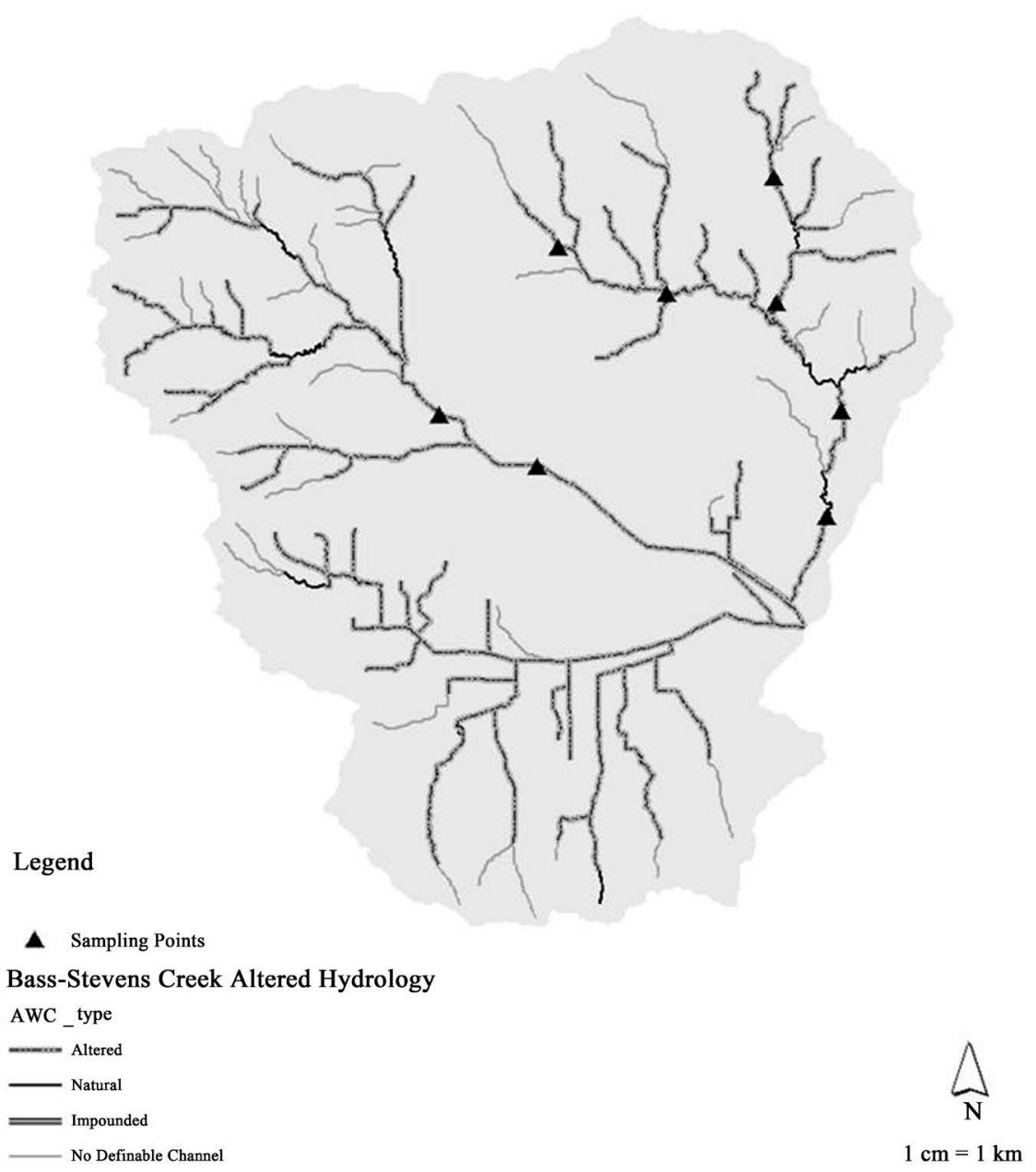

Figure 10. Bass-Stevens creek altered waterways. Note the majority of the points fall on impounded rivers.

Table 1. NLCD 2011 calculated land cover class percentages.

\begin{tabular}{|c|c|c|c|c|}
\hline Land Cover & $\begin{array}{c}\text { West Fork } \\
\text { Knapp Creek }\end{array}$ & $\begin{array}{c}\text { Bass-Stevens } \\
\text { Creek }\end{array}$ & Swamp Creek & $\begin{array}{c}\text { Milwaukee } \\
\text { River }\end{array}$ \\
\hline Developed & 3.8 & 5.6 & 1.9 & 79.9 \\
\hline Barren Land & 0.0 & 0.0 & 0.0 & 0.1 \\
\hline Forest & 63.9 & 3.4 & 49.4 & 5.5 \\
\hline Herbaceous/Shrub & 14.3 & 22.5 & 7.6 & 2.5 \\
\hline Cultivated Crops & 18.0 & 67.8 & 0.1 & 4.4 \\
\hline Wetlands & 0.1 & 0.7 & 39.0 & 6.0 \\
\hline Water & 0.0 & 0.0 & 2.1 & 1.6 \\
\hline
\end{tabular}

cent) than the other three watersheds. Specifically corn and soybean make up the highest percentage of the cultivated crop classification in Bass-Stevens Creek (58\%). Most of the streams in Bass-Stevens Creek were categorized as impounded (68 percent). West 


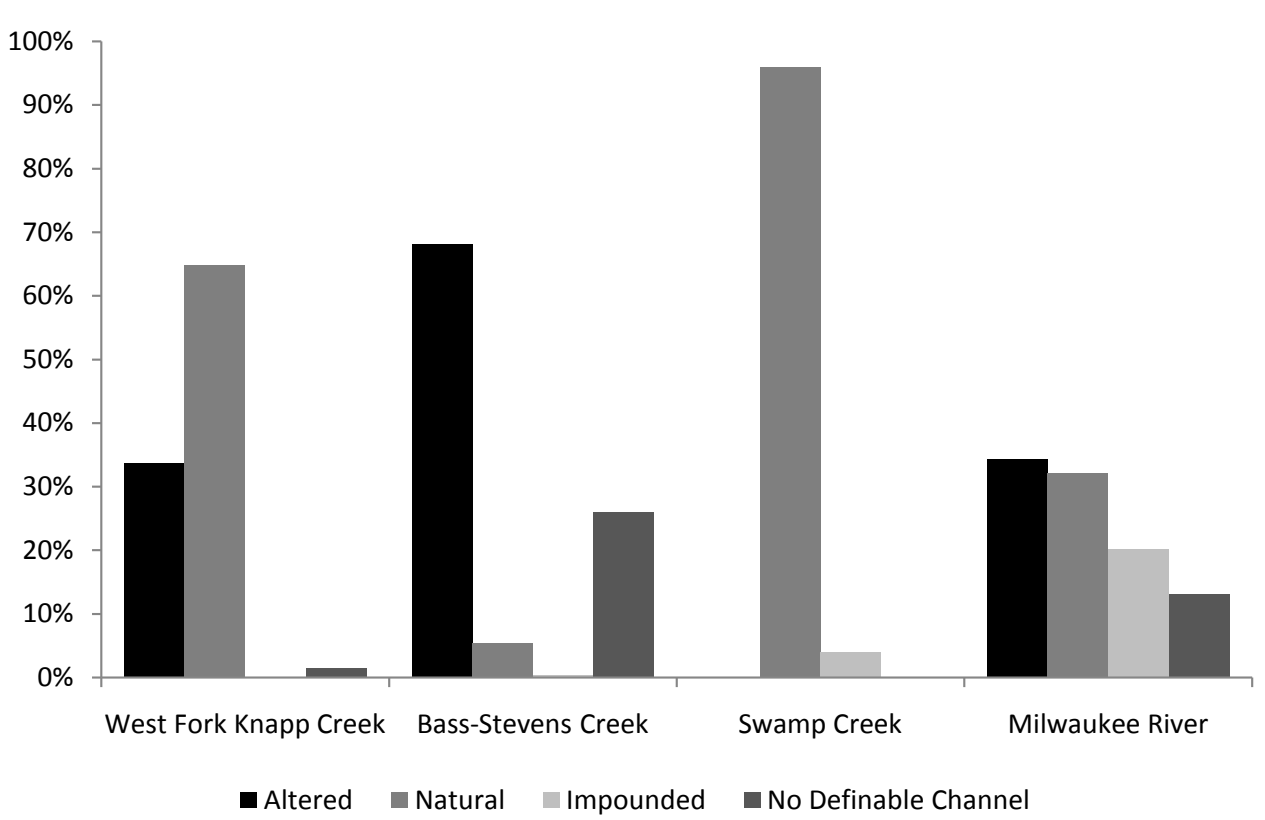

Figure 11. Classified stream hydrology percentages based on altered watercourse framework.

Fork Knapp Creek watershed has greater deciduous forest cover (63 percent) than the other watersheds based on USDA Cropland 2014 [22] and USGS 2011 [21] and also the highest percentage of natural streams (65 percent).

Swamp Creek, which is mainly deciduous forest and woody wetland land cover had the highest percent of natural streams (96 percent). A small percentage of Swamp Creek's hydrology (4 percent) were classified as impounded. The Milwaukee River has 80 percent of its landuse as urban developed. The watershed contained the most diverse waterways with 34 percent of classified as altered, 32 percent classified as natural, 20 percent classified as impounded, and 14 percent classified as no definable channel.

\subsection{Phosphorus Landuse and Altered Waterways}

As summarized in the methods section, the Milwaukee River $(\mathrm{n}=25)$ and Bass-Stevens Creek $(\mathrm{n}=8)$ watershed has several sampling points with total phosphorus $(\mathrm{mg} / \mathrm{L})$ data collected mostly during the last five years. The average of the data points for the Milwaukee River total phosphorus is 0.2 with a range of 0.09 to $0.47 \mathrm{mg} / \mathrm{L}$. The average for the Bass-Stevens watershed was 0.094 with a range of 0.04 to $0.16 \mathrm{mg} / \mathrm{L}$.

\subsection{Sub-Watersheds and Landuse}

The twenty-five sub-watersheds of the Milwaukee River watershed's landuse (ranging in drainage area $8-104 \mathrm{~km}^{2}$ ) were relatively homogenous. Most of the sub-watersheds had over 80 percent developed landuse, which was similar to the main watershed. The landuse range percentages for the sub-watersheds are as follows: developed landuse (40 - 100), agricultural ranged ( 0 - 46), forest $(0-11)$, and wetland $(0-10)$. The largest landuse ranges, developed and agricultural, were relatively homogenous with averages of 77 and 8 percent, respectively. One of the sub-watersheds had a very high agricultur- 
al landuse (46 percent) and low developed (40 percent), but the majority of the subwatersheds had less than 10 percent agricultural landuse and over 75 percent developed. Sub-watershed landuse was homogenous, so it was not used to compare total phosphorus values to percent landuse in any of the other categories with the exception of we Statistical tests confirmed visual assessment of the data revealing no statistically significant results in comparing sub-watershed landuse percentages to total phosphorus levels.

The eight sub-watersheds of Bass-Stevens Creek (ranging in drainage area 1.2 to 5.6 $\mathrm{km}^{2}$ ) were also similar to the main watershed landuse and relatively homogenous. Developed landuse ranged from 0 - 4 percent with an average of 3 percent. Forest landuse ranged from 0 - 3.5 percent with an average of 1.6 percent. Wetlands ranged from $0-4$ percent with an average of 1 percent. Cultivated crop landuse in this watershed did have a wider range from 32 to 100 percent with an average of 72 percent within the sub-watersheds. Statistical tests confirmed visual assessment of the data revealing no statistically significant results in comparing sub-watershed landuse percentages total phosphorus levels, with the exception of cultivated crops. The Mann Kendall trend test could not be used due to insufficient number of points (ten or more points are required). In Figure 12, the relationship between total phosphorus versus sub-watershed cultivated crop landuse percent has a correlation coefficient of 0.57 , which indicates that approximately 60 percent of the linear model presented is explained.

\subsection{Reach Scale (100-m Buffer) and Landuse}

For the Milwaukee River watershed, the 100-m buffers yielded a different story, perhaps in part due to a much higher heterogeneity, especially in the developed landuse percent than the sub-watershed. The landuse ranges percentages for the $100-\mathrm{m}$ buffers are as

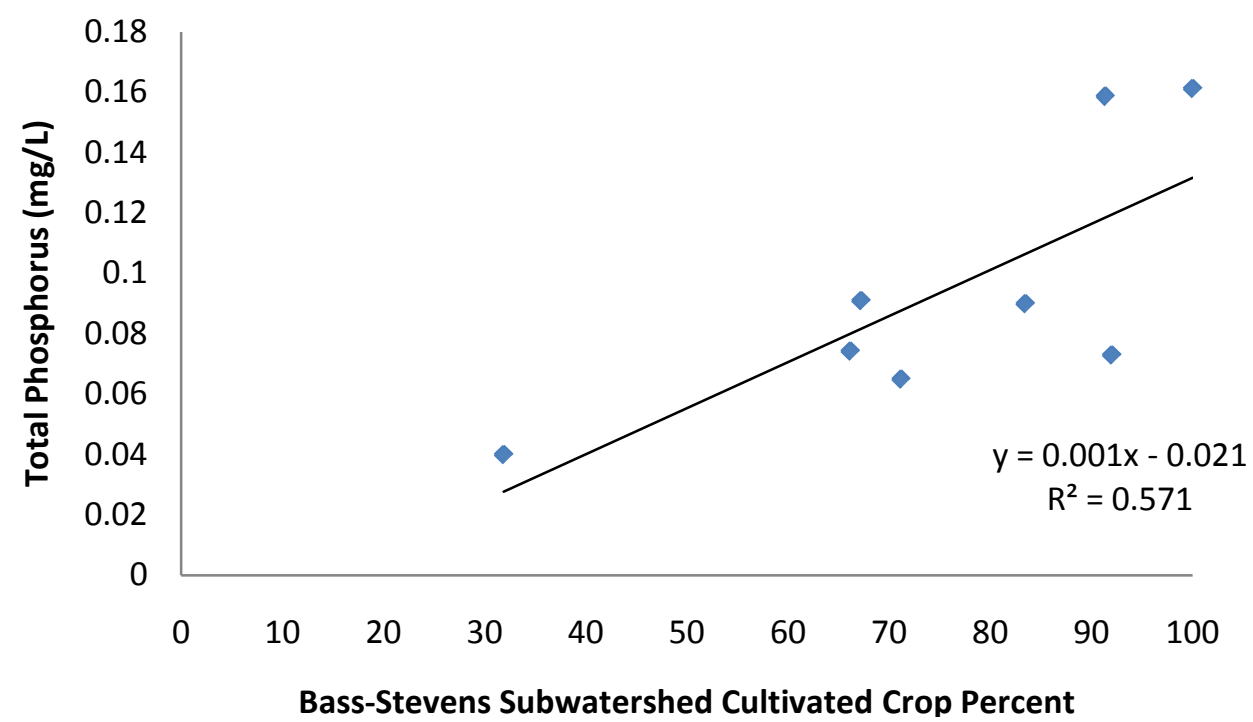

Figure 12. Total phosphorus for the dominant landuse (cultivated crop) in bass-stevens creek at the sub-watershed scale. 
follows: developed landuse ( 0 - 100), agricultural ranged $(0-5)$, forest $(0-30)$, and wetland $(0-65)$. Developed landuse percent compared to average total phosphorus $(\mathrm{mg} / \mathrm{l})$, shows a positive correlation up until 80 percent developed landuse Figure 13(a).

Around approximately 80 percent developed landuse and higher, the water quality sampling points show anomalously lower levels of total phosphorus Figure 13(a). These points were found on natural waterways. We removed the points with greater than eighty percent developed landuse. In Figure 13(b) the relationship between total

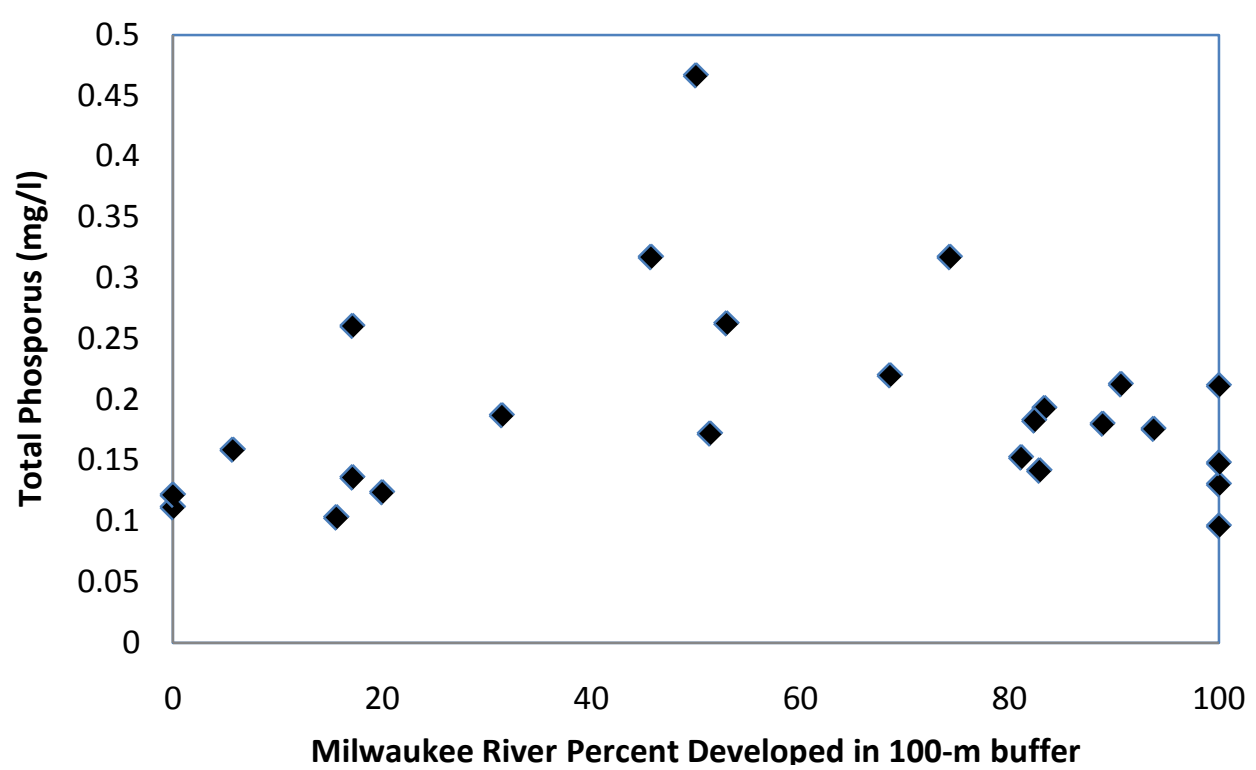

(a)

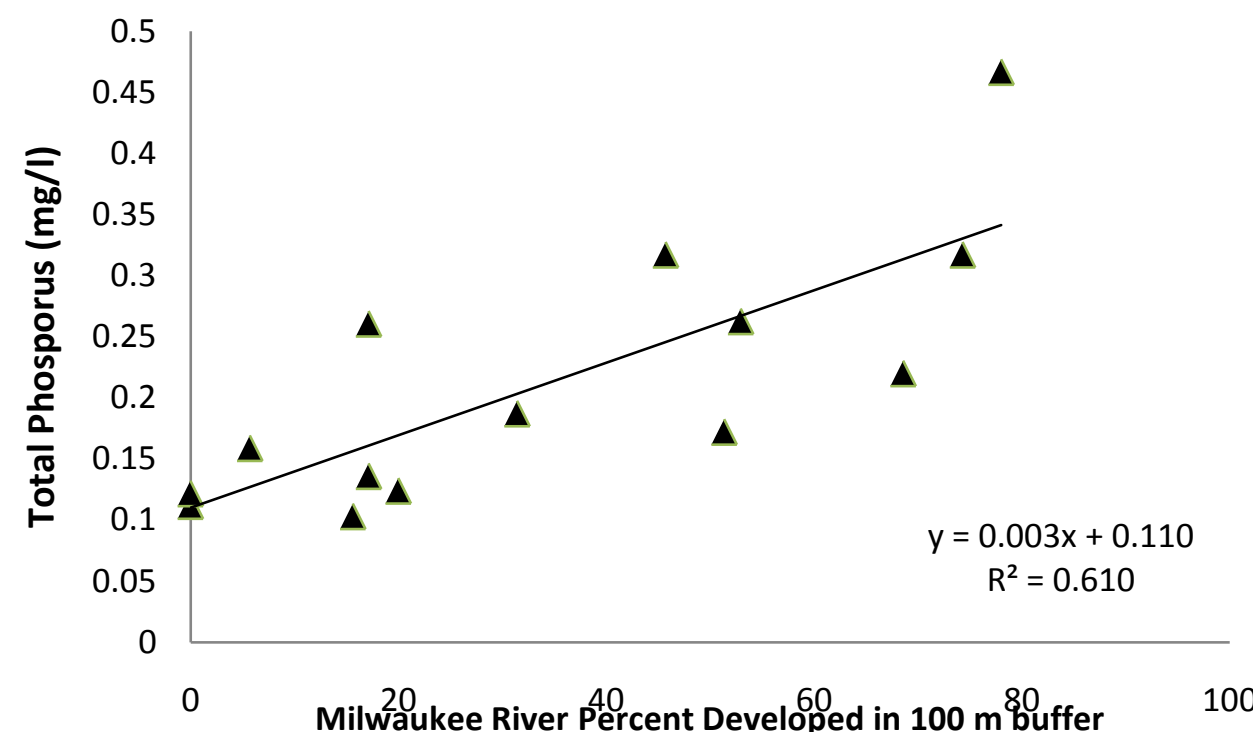

(b)

Figure 13. Total phosphorus for the dominant landuse (developed) in the Milwaukee river at the $100-\mathrm{m}$ buffer scale. The reading with low phosphorus levels but high developed landuse fall natural portions of the stream. 
phosphorus versus $100-\mathrm{m}$ buffer developed landuse percent has a correlation coefficient of 0.61 , which indicates that approximately 60 percent of the linear model presented is explained. Results of the Mann Kendall for the Milwaukee River 100-m buffer indicate that there is a significant positive trend $(\mathrm{p}<0.004)$ for phosphorus levels of the $100-\mathrm{m}$ buffer developed landuse from $0-80$ percent. For the entire range of $100-\mathrm{m}$ buffer developed landuse ( 0 - 100 percent), there is no significant trend $(\mathrm{p}>0.1)$.

The Bass-Stevens watershed 100-m buffer also yields different results from the subwatershed scale. The 100-m buffer zones have higher heterogeneity in many of the landuse categories. Developed landuse ranges from 17 to 69 percent with an average of 28 percent. Hay and pasture landuse ranges from 0 to 45 percent with an average of 14 percent, and forest ranges from 0 to 6 percent with an average of 3 percent, but both categories have five of the eight points with values of zero for the landuse percent. Cultivated crops landuse ranges from 25 to 82 percent with an average of 67 percent, and this was the only landuse category with enough heterogeneity to evaluate its relationship to total phosphorus. The correlation coefficient between total phosphorus versus 100 -m buffer cultivated crops was 0.001 , which indicates a model that has less 1 percent of the variance explained. It does not model the observed values and is statistically insignificant. As mentioned, the Mann Kendall trend test could not be used due to insufficient number of points (ten or more points are required).

\section{Discussion}

\subsection{Landuse and Altered Waterways}

Overall, the more anthropogenic landuse found within a watershed, the higher the amount of altered waterway classification (Figure 11). It is a little surprising to find the forested watershed (West Fork Knapp Creek) with over thirty percent of the waterways as altered, but it is unclear how much of that watershed supported logging activities that were prevalent in the $1800 \mathrm{~s}$ in Wisconsin. The agricultural (Bass-Stevens) watershed's results conform to assumptions associated with agricultural practices such as the straightening of streams [5]. The wetland (Swamp Creek) watershed waterway analysis results (less than 5 percent altered) conforms with studies of low anthropogenic impact [13]. The urban watershed (Milwaukee River) results, with the most heterogeneous classification of the waterways, may be indicative of heavily urban areas.

\subsection{Altered Waterways Link between Sub-Watershed and Reach Scale}

The Milwaukee River's is a predominately urban watershed. The 100-m buffer developed landuse percent ranged from $0-100$ percent. The eleven points in the range from 80 - 100 percent developed do not follow the increasing total phosphorus trend found in the other data points (between 0 - 80 percent developed). Six of those eleven points are on first order streams near the headwaters of the watershed (see Figure 9). The other five points are close to the main watershed's outlet and have over 95 percent developed landuse; therefore, we would expect them to have high total phosphorus levels. What is unique about these points is that they fall on or near the natural portion of the 
streams (see Figure 9). Both the position of the points within the watershed and the type of waterway that the point is on help to explain all of the points' significantly lower total phosphorus levels.

In the case of Bass-Stevens Creek, landuse within the 100-m buffer point does not have a statistically significant relationship with total phosphorus. Rather, the sub-watershed scale correlates better than the 100-meter buffer scale for cultivated crops versus total phosphorus. This difference from the Milwaukee River may be for several reasons. The sub-watersheds for Bass-Stevens Creek are smaller, where the largest sub-watershed $\left(5.6 \mathrm{~km}^{2}\right)$ was smaller than all of the Milwaukee River sub-watersheds. Unlike the Milwaukee River, Bass Steven's landuse is more homogenous. In Bass-Stevens Creek 90 percent of the landuse is associated with agriculture (where pasture and hay are considered agricultural landuse) while the Milwaukee River watershed is 80 percent developed (including low intensity development). Another difference between the two watersheds is the type of hydrologic classification. Bass-Stevens Creek is more homogenous based on classification, with approximately 70 percent altered and only 5 percent natural. The Milwaukee River has over 30 percent of its streams classified as natural. Finally, all of the Bass-Stevens Creek STORET sampling points $(n=8)$ were located onhydrologically altered waterways and several $(n=5)$ of Milwaukee River were on natural streams.

\subsection{Conclusions}

Altered waterways are highly correlated with watersheds that have more anthropogenic landuse. While this result confirms what is well documented in the literature, it also gives us additional information as to why larger scales (sub-watershed) landuse may not correlate well with water quality data such as phosphorus levels. In this paper, we found the Milwaukee River reach scale (100-m buffer) had a statically significant relationship between the dominant landuse (urban) and STORET phosphorus point data. In Stevens-Bass Creek, the sub-watershed scale showed a statistically significant relationship between the dominant landuse (agriculture) and phosphorus. Other studies have shown either a mix of scales to better correlate with water quality indicators [30] depending upon the indicator, while other studies found specific scales to be the best indicators [12] [31].

The Bass-Stevens Creek watershed finding of catchment scale landuse having a higher correlation to water quality indicators is similar to Silva and Williams (2013) who compared two scales (100-m buffer zones and whole catchment scale (sub-watershed) in a $332 \mathrm{~km}$ watershed of diverse landuse (forest, agricultural, and urban) [31]. They found the catchment scale more useful to predict water quality indicators [31]. Of note is the 100-m buffers landuse percentages were homogenous and the dominant landuse was less than 5 percent for most watersheds. By contrast, the catchment scale landuse was more heterogeneous, and had a wider range of the dominant landuse found in the watershed. Esselman and Allan (2010) also found at the catchment (sub-watershed) scale, abiotic factors were more statistically significant than at the reach scale $(100-\mathrm{m}$ buffer) scale for fish assemblages [12]. 
Esselman and Allan (2010) also note that the reach scale is still important and explained about 30 - 50 percent of the variance within their models [12]. Silvia and Williams (2013) [31] study found a similar finding to Esselman and Allan (2010). In the Silvia and Williams (2013) study, the correlation coefficient for reach (100-m buffer) and catchment (sub-watershed) scale factors differed by 10 percent [31]. The reach scale (100-m buffer) was not insignificant, just not as significant as catchment.

In this study we examined two watersheds with significant anthropogenic impacts to both landuse and the stream channels themselves, but we found differences in which scale explained the total phosphorus levels better. Bass-Stevens Creek and the Milwaukee River both have over 80 percent landuse that is associated with human alteration, but the Milwaukee River has 30 percent of its channels which are considered natural, by comparison to Bass-Stevens Creek, which has nearly all channels altered. In contrast to the Milwaukee River, all sampling points for Bass-Stevens were on the same type of stream alteration. The homogeneity of the Milwaukee River data combined with the observation that lower phosphorus levels were found along the natural portions of the river may suggest that alteration type is a factor that should be considered.

This study uses remote sensing and filtering techniques to identify stream alterations. Without using a GIS method developed by MNGeo (2011) [25] or one similar, the identification of stream alteration may have been difficult or impossible. Additionally, this method provides a method to link the larger sub-watershed scale to the reach scale and may address a way to remove autocorrelation associated with stream alteration and anthropogenic landuse.

\section{Acknowledgements}

The authors are grateful to Matt Diebel's help in retrieving the water quality data. M.J thanks Katherine Logan, Ashley Ignatius, Kelsey Budahn, Justin Watkins, Joe Magee, Bill Thompson, Casey Scott, Tiffany Schauls, Shaina Keseley, Ben Roush, Jen Ender, and Susanne Meader. The authors are also grateful to the University of Wisconsin-Stevens Point for the grant for a publication grant.

\section{References}

[1] Frissel, C.A., Liss, W.J., Warren, C.E. and Hurley, M.D. (1986) A Hierarchical Framework for Stream Habitat Classification: Viewing Streams in a Watershed Context. Environmental Management, 12, 199-214. http://dx.doi.org/10.1007/BF01867358

[2] Leopold, L.B., Wolman, M.G. and Miller, J.P. (1964) Fluvial Processes in Geomorphology. W.H. Freeman, San Francisco.

[3] Fausch, K.D., Torgersen, C.E., Baxter, C.V. and Li, H.W. (2002) Landscapes to Riverscapes: Bridging the Gap between Research and Conservation of Stream Fishes. Bioscience, 52, 483-498. http://dx.doi.org/10.1641/0006-3568(2002)052[0483:LTRBTG]2.0.CO;2

[4] Roth, N.E., Allan, J.D. and Ericson, D.L. (1996) Landscape Influences on Stream Biotic Integrity Assessed at Multiple Spatial Scales. Landscape Ecology, 11, 141-156. http://dx.doi.org/10.1007/BF02447513

[5] Allan, J.D., Ericson, D.L. and Fay, J. (1997) The Influence of Catchment Landuse on Stream 
Integrity across Multiple Spatial Scales. Freshwater Biology, 37, 149-161.

http://dx.doi.org/10.1046/j.1365-2427.1997.d01-546.x

[6] Forman, T. and Deblinger, R. (2000) The Ecological Road-Effect Zone of a Massachusetts (USA) Suburban Highway. Conservation Biology, 14, 36-46.

http://dx.doi.org/10.1046/j.1523-1739.2000.99088.x

[7] Wang, L., Lyons, J., Rasmussen, P., Seelback, P., et al. (2003) Watershed Reach, and Riparian Influences on Stream Fish Assemblages in the Northern Lakes and Forest Ecoregion, USA. Canadian Journal of Fisheries and Aquatic Sciences, 60, 491-505.

http://dx.doi.org/10.1139/f03-043

[8] Crenshaw, C.L., Grimm, N.B., Zeglin, L.H., Sheibley, R.W., Dahm, C.N. and Pershall, A.D. (2010) Dissolved Inorganic Nitrogen Dynamics in the Hyporheic Zone of Reference and Human-Altered Southwest US Streams. Fundamental and Applied Limnology/Archiv für Hydrobiologie, 176, 391-405. http://dx.doi.org/10.1127/1863-9135/2010/0176-0391

[9] Zavadil, E. and Stewardson, M. (2013) The Role of Geomorphology and Hydrology in Determining Spatial-Scale Units for Ecohydraulics. In: Ian, M., Atle, H., Paul, K. and Paul, W., Eds., Ecohydraulics: An Integrated Approach, Chapter 7, John Wiley and Sons, Hoboken, 125-142.

[10] Richards, C., Johnson, L.B. and Host, G.E. (1996) Landscape-Scale Influences on Stream Habitats and Biota. Canadian Journal of Fisheries and Aquatic Sciences, 53, 295-311. http://dx.doi.org/10.1139/f96-006

[11] Brazner, A. (2005) Impacts of Human Disturbances on Biotic Communities in Hawaiian Streams. Bioscience, 53, 1052-1060.

[12] Esselman, P. and Allan, J.D. (2010) Relative Influenzzces of Catchment- and Site-Scale Abiotic Factors on Fresh. Water Fish Communities in Rivers of Northeastern Mesoamerica. Ecology of Freshwater Fish, 19, 439-454. http://dx.doi.org/10.1111/j.1600-0633.2010.00430.x

[13] Allen, J.D. (2004) Landscapes and Riverscapes: The Influence of Landuse on Stream Ecosystems. Annual Review of Ecology and Systematics, 35, 257-284. http://dx.doi.org/10.1146/annurev.ecolsys.35.120202.110122

[14] WDNR (Wisconsin Department of Natural Resources) (2011) Total Maximum Daily Loads for Total Phosphorus and Total Suspended Solids in the Rock River Basin. 215 p. http://dnr.wi.gov/topic/TMDLs/RockRiver/FinalRockRiverTMDLReportWithTables.pdf

[15] WDNR (Wisconsin Department of Natural Resources) (2002) Water Details-Stevens Creek, Bass Creek Watershed (LR03). http://dnr.wi.gov/water/waterDetail.aspx?key=11632

[16] WDNR (Wisconsin Department of Natural Resources) (2007) 24K SHAID (Simple Hydro Areas) Version 6. GIS Vector Data. http://dnr.wi.gov/maps/gis/datahydro.html

[17] USDA (US Department of Agriculture) (2007) WBD (Watershed Boundary Dataset) 2007. GIS Vector Data. http://nhd.usgs.gov/data.html

[18] Wisconsin View (2011) LiDAR (Light Detection and Ranging), Digital Elevation Model Raster. http://www.wisconsinview.org/

[19] Wisconsin View (2013) NAIP (National Agricultural Imaging Program), Imagery. Raster Digital Data. http://www.wisconsinview.org/

[20] WHAIF (Wisconsin Historic Aerial Imagery Finder) (2010) Historic 1938 Aerial Imagery. Raster Digital Data. http://maps.sco.wisc.edu/WHAIFinder/

[21] USFWS (US Fish and Wildlife Service) (2015) NWI (National Wetland Inventory). GIS Vector Data. http://www.fws.gov/wetlands/Data/Mapper.html 
[22] USGS (US Geological Survey) (2011) NLCD (National Land Cover Database) 2011 Land Cover. SDE Raster Digital Data. http://www.mrlc.gov/nlcd2011.php

[23] USDA (US Department of Agriculture) (2014) NASS (National Agricultural Statistics Service) CDL (2014 Cropland Data Layer) SDE Raster Digital Data. http://www.nass.usda.gov/Statistics_by_State/Wisconsin/

[24] WDOT (Wisconsin Department of Transportation) (2003) WISLR (Wisconsin Information System for Local Roads) Transportation Lines. GIS Vector Data.

http://wisconsindot.gov/Pages/doing-bus/local-gov/wislr/default.aspx

[25] MnGeO (Minnesota Geospatial Information Office) (2011) Altered Watercourse Determination Methodology. 55 p.

http://www.pca.state.mn.us/index.php/water/water-types-and-programs/surface-water/stre ams-and-rivers/minnesota-statewide-altered-watercourse-project.html

[26] Smith, C.E. (1998) Modeling High Sinuosity Meanders in a Small Flume. Geomorphology, 25, 19-30. http://dx.doi.org/10.1016/S0169-555X(98)00029-4

[27] Diebel, M.W., Ruesch A.S., Menuz, D., Stewart, J. and Westenbroek, S.M. (2015) Ecological Limits of Hydrologic Alteration in Wisconsin Streams. Wisconsin Groundwater Management Practice Monitoring Project, [DNR-209-Revised], 70 p.

[28] Kendall, M.G. (1975) Rank Correlation Methods. 4th Edition, Charles Griffin, London.

[29] Helsel, D. and Hirsch R. (2002) Statistical Methods in Water Resources. US Geological Survey, Techniques of Water-Resources Investigations Book 4, Chapter A3, 522 .

[30] Wang, G., Yinglan, A., Xu, Z., and Zhang S. (2014) The Influence of Landuse Patterns on Water Quality at Multiple Spatial Scales in a River System. Hydrological Processes, 28, 5259-5272. http://dx.doi.org/10.1002/hyp.10017

[31] Sliva, L. and Williams, D. (2001) Buffer Zone versus Whole Catchment Approaches to Studying Landuse Impact on River Water Quality. Water Research, 35, 3462-3472. http://dx.doi.org/10.1016/S0043-1354(01)00062-8

\section{Submit or recommend next manuscript to SCIRP and we will provide best service} for you:

Accepting pre-submission inquiries through Email, Facebook, LinkedIn, Twitter, etc. A wide selection of journals (inclusive of 9 subjects, more than 200 journals)

Providing 24-hour high-quality service

User-friendly online submission system

Fair and swift peer-review system

Efficient typesetting and proofreading procedure

Display of the result of downloads and visits, as well as the number of cited articles Maximum dissemination of your research work

Submit your manuscript at: http://papersubmission.scirp.org/ 